\title{
Cytological and Biochemical Effects of St. John's Wort Supplement (A Complex Mixture of St. John's Wort, Rosemary and Spirulina) on Somatic and Germ Cells of Swiss Albino Mice
}

\author{
A. M. Aleisa* \\ Department of Pharmacology, College of Pharmacy, King Saud University, P. O. Box 2457, Riyadh-11451, Saudi Arabia \\ "Correspondence to Dr. A. M. Aleisa. E-mail: aleisa@gmail.com
}

Received: 22 April 2008 / Accepted: 04 August 2008 / Published: 31 December 2008

\begin{abstract}
Commercially available St. John's wort supplement (SJWS) composed of an herbal mixture of St. John's Wort (SJW), Rosemary (RM) and Spirulina (SP) is used as a dietary supplement for the treatment of psychiatric disorders. Although the minor ingredients, (RM and SP) are proven antioxidants, their quantity is quite insignificant as compared to the SJW, which is the major ingredient. Most of the toxic effects of SJWS are attributed to the main constituents of SJW which differ due to the influence of light (hypericin) and variations in temperature above freezing point (hyperforin). However, there are no reports on toxicity of SJWS maintained at room temperature in pharmacies and supermarkets. In view of the folkloric importance, immense (prescribed or unprescribed) use and a paucity of literature on SJWS, it was found worthwhile to (1) determine the genotoxic effects of SJWS in somatic and germ cells of mice and (2) investigate the role of biochemical changes, as a possible mechanism. The protocol included the oral treatment of mice with different doses (380, 760 and $1520 \mathrm{mg} / \mathrm{kg} /$ day) of SJWS for 7 days. The following experiments were conducted: (i) cytological studies on micronucleus test, (ii) cytogenetic analysis for meiotic chromosomes, (iii) cytological analysis of spermatozoa abnormalities, (iv) quantification of proteins and nucleic acids in hepatic and testicular cells and (v) estimation of malondialdehyde (MDA) and nonprotein sulfhydryl (NP-SH) in hepatic and testicular cells. The treatment increased the frequency of micronuclei in polychromatic erythrocytes (PCE) in the femora. It caused aberrations in chromosomes of testes and induced spermatozoa abnormalities. These changes might be attributed to the epigenetic mechanisms as revealed by an increase in concentrations of MDA and depletion of nucleic acids and NP-SH levels in both hepatic and testicular cells observed in the present study. Since, the samples of SJWS used were not drawn from extremities of light and temperature; the observed effect might not be related to the main constituents of SJW. However, these changes might be ascribed to the combined effect of terpenes, tannins, quercetin and flavonoids present in SJW.
\end{abstract}

Keywords: St. John’s Wort Supplement; cytology; somatic cells; germ cells; nucleic acids; malondialdehyde; nonprotein sulfhydryl groups.

\section{Introduction}

Commercially available St. John's Wort suplement (SJWS) composed of St. John's Wort, (SJW), Rosemary (RM) and Spirulina (SP) is used as a dietary supplement for the treatment of psychiatric disorders. SJW is the major ingredient present in SJWS capsule to the extent of $300 \mathrm{mg}$. It has folkloric importance in treatment of depression, insomnia, exhaustion, somatoform disorders, nervosity, and convalescence; in addition to its uses as a remedy for skin diseases, superficial injury, mucosal lesions and gastrointestinal illness [1]. In view of its folkloric relevance, SJW has been widely experimented and reports in the literature endorse both beneficial and adverse effects. It has been found to protect against the apoptosis induced by $\mathrm{H}_{2} \mathrm{O}_{2}$ in human neuroblastoma cells and is shown to inhibit the free radical production in both cell-free and human vascular tissue [2]. Hunt et al. [3] observed SJW to produce a pro-oxidant effect at the high dose and antioxidant properties at low dose. On the other hand, studies on reproductive toxicity showed SJW to possess spermicidal effect, as revealed by inhibition of sperm motility and it had an adverse effect on oocytes and weight of newborn [4]. SJW was also demonstrated to be 
mutagenic to sperm cells. It is also known to cause a severe damage in both livers and kidneys of Wister rats [5]. Furthermore, studies on toxicity of SJW revealed it to cause erythema, edema, alopecia, reduction in weight and changes in blood chemistry, in addition to skin reddening, itching, dizziness, constipation, fatigue, anxiety and tiredness in both humans and animals [6, 7]. The itching types of erythematous lesions were specific to lightexposed areas [6]. In sheep, Kumper [8] observed adverse reactions, including skin reddening and itching, dizziness, constipation, fatigue, anxiety, and tiredness, especially in the hairless pigmented parts (ears, the bridge of the nose at the surroundings of the eyes). The author came up with a suggestion that the observations are inflammatory skin alterations related with photoreactions. Exposure of SJW to light illumination is described to potentiate the growth inhibitory and apoptotic effects on K562, U937, LN229 glioblastoma cell lines and normal human astrocytes [9].

Analysis of constituents in SJW revealed the presence of hypericin, hyperforin, naphtodianthrones, flavonoids, terpenes, sesquiterpene oils, phenylpropanes, biflavones, tannins, xanthones and phloroglucinols [7, 10]. The major components are hypericin and hyperforin. Hypericin is known to possess antiviral activity against the enveloped viruses that includes the human immunodeficiency virus [11]. The toxicity of hypericin towards viruses and tumors absolutely requires light $[11,12]$ On the other hand hyperforin, the other component of SJW has the tendency to degrade at temperatures higher than $-70^{\circ} \mathrm{C}$ [13]. It has been shown to possess a pronounced antitumor effect against different tumor cell lines, both in vitro and in vivo and has been shown to possess apoptosis-associated cytotoxic effect in both murine and human tumor cells and is found to check metastatic growth [14].

Rosemary (RM) is a minor ingredient present in SJWS capsule to the extent of $80 \mathrm{mg}$. It is a common household plant grown in many parts of the world. As a proven antioxidant, it is used for flavoring food, as a beverage drink and as well as in cosmetics. In folk medicine, it is used as an antispasmodic in renal colic and dysmenorrhoea, in relieving respiratory disorders and to stimulate growth of hair. Extrtact of rosemary relaxes smooth muscles of trachea and intestine, and has choleretic, hepatoprotective and antitumerogenic activity $[15,16]$. The constituents (caffeic acid, rosmarinic acid, carnosol or carnosic acid) are reported to possess antioxidant properties [15-17]. Sancheti and Goyal, [18] found it to protect against 7, 12-dimethylbenz(a) anthracene (DMBA)-induced skin tumorigenesis in mice at a dose of $500 \mathrm{mg} / \mathrm{kg}$ body weight per mouse. Rosmarinic acid, a phenolic constituent of rosemary has been found to have fibrinolytic and antioxidative activity [17]. Anadon et al. [19] found the extracts of rosemary to be safe upto a dose of $2000 \mathrm{mg} / \mathrm{kg}$ of body weight in Wistar rats. The treatment had no adverse effects or mortality for a period of 2 weeks. The components of rosemary have been found to inhibit benzo[a] pyreneinduced genotoxicity in human bronchial cells [15].
Spirulina (SP) (another minor ingredient present in SJWS capsule to the extent of $40 \mathrm{mg}$ ) is unicellular filamentous blue - green algae, consumed by man since ancient times in Mexico and central Africa. Initially the interest in Spirulina was on its nutritive value for its protein content. More recently, some preclinical testing suggests it has several therapeutic properties such as hypocholesterolemic, immunological, antiviral and antimutagenic. In animal experiments for acute, subchronic and chronic toxicity, reproduction, mutagenicity, and teratogenicity, the algae did not cause body or organ toxicity [20]. Khan et al. [21] reported Spirulina to possess bio-modulatory, immuno-modulatory, anticarcinogenic and antioxidant properties and it protect tissues and reduce toxicity of liver, kidney and testes caused by any toxin. The constituents present in Spirulina are physcocyanin, b-carotene, polyunsaturated acids and super oxide dismutase [22]. Spirulina is found to protect against the cardiotoxicity induced by doxorubicin [21] and Cyclophosphamide (CP)-induced genetic damage [23]. The addition of Spirulina to SJWS capsule is perhaps to avert the proven toxicity of SJW.

A large number of papers are published on the pharmacology and toxicology effects of the different ingredients of SJWS (SJW, RM and SP) and their constituents. However, in view of the major contents of SJW, the most interesting constituents are hypericin and hyperforin, which differ due to the influence of light and variations in temperature above freezing point, respectively. Nevertheless, there is a paucity of literature on genotoxicity and biochemical toxicity of SJWS maintained at room temperature at pharmacies and supermarkets. The present study on the cytological and biochemical effects of SJWS in somatic and germ cells of Swiss albino mice was undertaken in view of its folkloric importance, immense (prescribed or unprescribed) use and a paucity of literature on combined use of SJW, RM and SP.

\section{Materials and Methods}

\section{Test Herbal Product}

SJWS (Batch No. 246261, manufacturing date November, 2005) was used as the test product in the present study. It is marketed as dietary supplement by Nature's way product (USA) in form of capsules. Each capsule contained $300 \mathrm{mg}$ of St. John's Wort (SJW), 80 mg of Rosemary (RM) leaf and $40 \mathrm{mg}$ of Spirulina (SP) (algae).

\section{Animal Stocks}

Male Swiss albino mice (SWR), 6-8 weeks old and weighing 25-28g, were obtained from the Experimental Animal Care Center, King Saud University, Riyadh, Saudi Arabia. The animals were fed on Purina chow diet and water ad libitum and were maintained under standard conditions of humidity, temperature, and light (12 h, 
light/12 dark cycle). The conduct of experiments and the procedure of sacrifice (using ether) were approved by the Ethics Committee of the Experimental Animal Care Society, College of Pharmacy, King Saud University, Riyadh, Saudi Arabia.

\section{Dose, Route and Duration of Treatment}

The dose of SJWS was determined by (i) Maximum Tolerated Dose (MTD) (ii) Human therapeutic dose with reference to the surface area rule and (iii) preliminary experiments conducted in our laboratory and reports in the literature [5, 24]. On the basis of evaluated MTD, (6.00 $\mathrm{gm} / \mathrm{kg}$.), the doses of SJWS selected were 380, 760 and $1520 \mathrm{mg} / \mathrm{kg} /$ day corresponding to $1 / 16 \mathrm{th}, 1 / 8$ th and $1 / 4$ th, respectively [25]. The daily recommended dose of SJWS (as inscribed on the commercially available bottle) for an adult human is $900 \mathrm{mg}$ (3 capsules). According to the rule of surface area ratio of mice (20 g) and man (60 kg), the calculated ratio is 0.0026 and the dose of SJWS (per 50 mice weighing $1 \mathrm{~kg})$ would be $117.0 \mathrm{mg} / \mathrm{kg}(0.0026 \mathrm{x} 900 \mathrm{x}$ $50=117.0 \mathrm{mg} / \mathrm{kg}$.). The dose used experimentally is generally six times more than the calculated value (117 x 6 $=702.0 \mathrm{mg} / \mathrm{kg} /$ day $)$. This is because the metabolic rate is more in mouse as compared to human being [26]. The medium dose (760 mg/kg/day) selected in the present study was based on the recommended human dose and the surface area rule and was around $1 / 8^{\text {th }}$ of MTD. The low (380) and high (1520 mg/kg/day) doses were approximately half and double the dose selected, respectively. Aqueous suspension of SJWS was administered by gastric intubation (oral) per $\mathrm{kg} /$ day for seven days.

\section{Experimental Groups}

The experimental groups of mice consisted of the following: group 1 , control $(0.3 \mathrm{ml} /$ mouse, tap water $)$; group 2, SJWS (380 mg/kg/day); group 3, SJWS (760mg/kg/day); group 4, SJWS (1520 mg/kg/day). In each case, a total of 30 mice were used as follows: (i) Cytological studies on micronucleus test, in cells from femoral bone marrow (5 mice); (ii) evaluation of meiotic chromosomal aberrations (5 mice); (iii) analysis of spermatozoa abnormalities (5 mice); (iii) estimation of proteins and nucleic acids in testicular cells (5 mice); (iv) estimation of malondialdehyde (MDA) and nonprotein sulfhydryl (NP-SH) in hepatic cells (5 mice); (vii) evaluation of MDA and NP-SH in testicular cells (5 mice).

\section{Cytological Studies on Micronucleus Test}

The procedure of micronucleus test described by Schmid [27] was followed. The cells from femoral bone marrow were collected in fetal calf serum. After centrifugation, the cells were spread on slides and airdried. Coded slides were fixed in methanol and stained in May-Gruenwald solution followed by Giemsa stain. The polychromatic erythrocytes (PCE) were screened for micronuclei, and normochromatic erythrocytes (NCE) were screened to obtain the ratio of mitotic index. The reduction of the mitotic index was assessed on the basis of the ratio of PCE/NCE.

\section{Cytogenetic Analysis for Meiotic Chromosomes}

In the analysis of meiotic chromosomal aberrations, the mice were sacrificed on 19th day from the last treatment day [28]. The testes were removed and placed in $2.2 \%$ isotonic sodium citrate solution. The tunica albugenia was peeled out and seminiferous tubules were teased to form a cell suspension. The suspension was centrifuged and the pellet re-suspended in $1.1 \%$ hypotonic sodium citrate solutions. After centrifugation the supernatant was discarded and the pellet suspended in fixative (methanol and acetic acid, 3:1). The chromosomal preparations were made by the air drying technique [28]. The coded slides were stained in Giemsa solution (10 per cent), spermatocytes at the diakinesis-metaphase I stages were examined for chromosomal aberrations including aneuploids, autosomal univalents, sex-univalents, polyploids and translocations.

\section{Cytological Analysis of Spermatozoa Abnormalities}

The mice were sacrificed 5 weeks after the last day of sub-acute treatment [28]. The spermatozoa were obtained by making small cuts in caudae epididymis and vas deferens placed in $1 \mathrm{ml}$ of modified Krebs Ringerbicarbonate buffer ( $\mathrm{pH}$ 7.4). The sperm suspension obtained was stained with $0.05 \%$ of eosin-Y; smears were made on slides, air-dried and made permanent. The spermatozoa morphology was examined by bright-field microscopy with an oil immersion lens. The different spermatozoa abnormalities (amorphous, banana shaped, swollen achrosome, triangular head, macrocephali and rotated head) screened were those found in all the slides [28].

Evaluation of Proteins, Nucleic Acids, MDA and NP-SH in Liver and Testis

The frozen samples (liver and testis) were used for estimation of proteins, ribose nucleic acid (RNA), deoxyribose nucleic acid (DNA), MDA and NP-SH.

\section{Estimation of Total Proteins and Nucleic Acids}

Total proteins were estimated by the modified Lowry method of Schacterle and Pollack [29]. Bovine serum albumin was used as standard. The method described by Bregman [30] was used to determine the levels of nucleic acids. The sample tissues were homogenized and the homogenate was suspended in ice-cold trichloroacetic acid (TCA). After centrifugation, the pellet was extracted with ethanol. The levels of DNA were determined by treating the nucleic acid extract with diphenylamine reagent and reading the intensity of blue color at $600 \mathrm{~nm}$. For 
quantification of RNA, the nucleic acid extract was treated with orcinol and the green color was read at $660 \mathrm{~nm}$. Standard curves were used to determine the amounts of nucleic acids present.

\section{Determination of MDA Concentrations}

The method described by Ohkawa et al. [31] was followed. The sample tissues were homogenized in TCA and the homogenate suspended in thiobarbituric acid. After centrifugation the optical density of the clear pink supernatant was read at $532 \mathrm{~nm}$. Malondialdehyde bis (dimethyl acetal) was used as an external standard.

Quantification of the NP-SH Levels

The method described by Sedlak and Lindsay

[32] was followed to determine the levels of NP-SH. The sample tissues were homogenized in ice-cold $0.02 \mathrm{M}$ ethylene-o-amine tetra acetic acid disodium (EDTA) and mixed with TCA. The homogenate was centrifuged at $3000 \mathrm{~g}$. The supernatant was suspended in tris buffer, 5-5'dithiobis-(2 nitrobenzoic acid) (DTNB) and read at 412 $\mathrm{nm}$ against reagent blank with no homogenate.

\section{Statistical Analysis}

Analysis of variance and Post hoc Tukey-Kramer multiple comparison tests statistically analyzed the different studies undertaken.

\section{Results} to 5 .

The results of this study are summarized in Tables 1

Table 1: Effect of St. John's Wort Supplement on the frequency of micronuclei and the ratio of polychromatic to normochromatic erythrocytes from femoral bone marrow of Swiss albino mice after sub-acute treatment

\begin{tabular}{|l|c|c|c|}
\hline $\begin{array}{l}\text { Treatment and dose (mg/kg. Body } \\
\text { weight) }\end{array}$ & $\begin{array}{c}\text { Polychromatic } \\
\text { erythrocytes (PCE) } \\
\text { screened }\end{array}$ & $\begin{array}{c}\text { Polychromatic } \\
\text { erythrocytes (\%) } \\
\text { (Mean } \pm \text { S.E.) }\end{array}$ & $\begin{array}{c}\text { Normochromatic } \\
\text { erythrocytes (NCE) } \\
\text { Screened }\end{array}$ \\
\hline Control (0.3 ml tap water/mouse) & 5600 & $0.35 \pm 0.07$ & 5200 \\
\hline St. John's Wort Supplement (380) & 5400 & $0.46 \pm 0.08$ & 4500 \\
\hline St. John's Wort Supplement (760) & 5800 & $0.59 \pm 0.04 *$ & $1.08 \pm 0.06$ \\
\hline St. John's Wort Supplement (1520) & 6000 & $0.74 \pm 0.09 * *$ & 5200 \\
\hline
\end{tabular}

Five mice were used in each group

${ }^{*} \mathrm{p}<0.05$; ${ }^{* *} \mathrm{p}<0.01$ (One way ANOVA and Post hoc Tukey-Kramer multiple comparison test was done individually for different parameters).

Table 2: Effect of St. John's Wort Supplement on testis chromosomes in Swiss albino mice after sub-acute treatment

\begin{tabular}{|c|c|c|c|c|}
\hline $\begin{array}{l}\text { Different chromosomal } \\
\text { abnormalities screened/Total }\end{array}$ & \multicolumn{4}{|c|}{ Treatments and dose (mg/kg. Body weight/day)/percent chromosomal aberrations (Mean \pm S.E.) } \\
\hline Aneuploids & $3.24 \pm 0.67$ & $4.65 \pm 0.72$ & $6.18 \pm 0.79 *$ & $6.85 \pm 0.68^{* *}$ \\
\hline Autosomal univalents & $2.87 \pm 0.53$ & $3.32 \pm 0.45$ & $2.22 \pm 0.23$ & $2.46 \pm 0.26$ \\
\hline Polyploids & $2.30 \pm 0.45$ & $3.16 \pm 0.40$ & $4.49 \pm 0.66^{*}$ & $5.35 \pm 0.26 *$ \\
\hline Total-percent aberrations & $10.75 \pm 1.59$ & $14.86 \pm 1.35$ & $15.57 \pm 0.98^{*}$ & $16.07 \pm 0.83^{*}$ \\
\hline
\end{tabular}

Five mice were used in each group

${ }^{*} \mathrm{p}<0.05,{ }^{* *} \mathrm{p}<0.01 \quad$ (One-way ANOVA and Post hoc Tukey-Kramer multiple comparison test was done individually for different parameters). 
Table 3: Effect of St. John's Wort Supplement on epididymal spermatozoa in Swiss albino mice after sub-acute treatment

\begin{tabular}{|l|c|c|c|r|}
\hline \multirow{2}{*}{$\begin{array}{l}\text { Different Spermatozoal } \\
\text { abnormalities } \\
\text { screened/Total }\end{array}$} & \multicolumn{2}{|c|}{ Treatments and dose (mg/kg. Body weight/day)/percent sperm abnormalities (Mean \pm S.E.) } \\
\cline { 2 - 5 } & $\begin{array}{c}\text { Control (tap water, 0.3 } \\
\text { ml/mouse/day) }\end{array}$ & $\begin{array}{c}\text { St. John's Wort } \\
\text { Supplement (380) }\end{array}$ & $\begin{array}{c}\text { St. John's Wort } \\
\text { Supplement (760) }\end{array}$ & $\begin{array}{r}\text { St. John's Wort } \\
\text { Supplement (1520) }\end{array}$ \\
\hline Amorphous & $0.43 \pm 0.08$ & $0.53 \pm 0.21$ & $0.66 \pm 0.17$ & $0.74 \pm 0.19$ \\
\hline Banana shaped & $0.35 \pm 0.07$ & $0.56 \pm 0.16$ & $0.58 \pm 0.31$ & $0.68 \pm 0.11^{*}$ \\
\hline Swollen achrosome & $0.37 \pm 0.05$ & $0.66 \pm 0.21$ & $0.59 \pm 0.16$ & $0.70 \pm 0.11^{*}$ \\
\hline Triangular head & $0.29 \pm 0.03$ & $0.58 \pm 0.16$ & $0.59 \pm 0.18$ & $0.82 \pm 0.21^{*}$ \\
\hline Macrocephali & $0.37 \pm 0.05$ & $0.56 \pm 0.14$ & $0.45 \pm 0.06$ & $0.62 \pm 0.23$ \\
\hline Rotated head & $0.06 \pm 0.03$ & $0.13 \pm 0.02$ & $0.05 \pm 0.02$ & $4.52 \pm 0.84^{*}$ \\
\hline Total abnormalities & $1.88 \pm 0.24$ & $4.00 \pm 0.99$ & $3.14 \pm 0.74$ & 5030 \\
\hline Total sperms screened & 5080 & 5270 & 5330 & 0.09 \\
\hline
\end{tabular}

Five mice were used in each group

${ }^{*} \mathrm{p}<0.05$ (One way ANOVA and Post hoc Tukey-Kramer multiple comparison test was done individually for different parameters).

Table 4: Effect of St. John's Wort Supplement on Protein and Nucleic acid contents in hepatic and testicular tissue of Swiss albino mice after Sub-acute treatment

\begin{tabular}{|c|c|c|c|c|c|c|}
\hline \multirow[b]{2}{*}{$\begin{array}{l}\text { Treatment and Dose } \\
(\mathrm{mg} / \mathrm{kg} . \text { Body weight })\end{array}$} & \multicolumn{3}{|c|}{ Hepatic tissue (Mean \pm S.E.) } & \multicolumn{3}{|c|}{ Testicular tissue (Mean \pm S.E.) } \\
\hline & $\begin{array}{c}\text { Proteins } \\
\text { (mg/100 mg } \\
\text { tissue) }\end{array}$ & $\begin{array}{c}R N A \\
(\mu g / 100 m g \\
\text { tissue })\end{array}$ & $\begin{array}{c}D N A \\
(\mu g / 100 m g \\
\text { tissue })\end{array}$ & $\begin{array}{l}\text { Proteins } \\
\text { (mg/100 mg } \\
\text { tissue) }\end{array}$ & $\begin{array}{c}R N A \\
(\mu g / 100 m g \\
\text { tissue) }\end{array}$ & $\begin{array}{r}D N A(\mu g / 100 m g \\
\text { tissue })\end{array}$ \\
\hline $\begin{array}{l}\text { Control (tap water, } 0.3 \\
\mathrm{ml} / \mathrm{mouse} \text { ) }\end{array}$ & $14.23 \pm 0.56$ & $638.20 \pm 20.83$ & $120.00 \pm 3.27$ & $10.97 \pm 0.19$ & $369.20 \pm 7.16$ & $234.04 \pm 17.52$ \\
\hline $\begin{array}{l}\text { St. John’s Wort } \\
\text { Supplement (380) }\end{array}$ & $13.42 \pm 0.67$ & $583.80 \pm 25.34$ & $109.40 \pm 3.74$ & $11.67 \pm 0.52$ & $364.20 \pm 11.55$ & $227.04 \pm 8.34$ \\
\hline $\begin{array}{l}\text { St. John's Wort } \\
\text { Supplement (760) }\end{array}$ & $12.96 \pm 0.34$ & $591.00 \pm 16.99$ & $109.60 \pm 4.30$ & $11.32 \pm 0.34$ & $355.20 \pm 13.43$ & $207.40 \pm 18.01$ \\
\hline $\begin{array}{l}\text { St. John's Wort } \\
\text { Supplement (1520) }\end{array}$ & $12.76 \pm 0.67$ & $558.00 \pm 13.39 *$ & $101.20 \pm 4.68 *$ & $11.44 \pm 0.48$ & $324.80 \pm 11.89$ & $186.08 \pm 8.73^{*}$ \\
\hline
\end{tabular}

Five mice were used in each group

${ }^{*} \mathrm{p}<0.05$; (One way ANOVA and Post hoc Tukey-Kramer multiple comparison test was done individually for male, female and different parameters)

Table 5: Effect of St. John's Wort Supplement on Malondialdehyde and Glutathione (NP-SH) concentrations in liver and testes of mice after sub-acute treatment

\begin{tabular}{|c|c|c|c|c|}
\hline \multirow[b]{2}{*}{$\begin{array}{l}\text { Treatment and dose }(\mathrm{mg} / \mathrm{kg} \text {. Body } \\
\text { weight. }\end{array}$} & \multicolumn{2}{|c|}{ Hepatic tissue } & \multicolumn{2}{|c|}{ Testicular tissue } \\
\hline & $\begin{array}{c}\text { Malondialdehyde } \\
\text { concentrations } \\
\text { (nmol/g wet tissue) } \\
\text { Mean } \pm \text { S.E }\end{array}$ & $\begin{array}{c}\text { NP-SH concentration } \\
\text { (nmol/100 mg wet } \\
\text { tissue) } \\
\text { Mean } \pm \text { S.E }\end{array}$ & $\begin{array}{c}\text { Malondialdehyde } \\
\text { concentrations } \\
\text { (nmol/g wet tissue) } \\
\text { Mean } \pm \text { S.E }\end{array}$ & $\begin{array}{r}\text { NP-SH concentration } \\
\text { (nmol/100 mg wet } \\
\text { tissue) } \\
\text { Mean } \pm \text { S.E }\end{array}$ \\
\hline Control (tap water, $0.3 \mathrm{ml} / \mathrm{mouse}$ ) & $225.00 \pm 9.58$ & $185.20 \pm 7.32$ & $202.60 \pm 9.25$ & $114.20 \pm 6.42$ \\
\hline St. John’s Wort Supplement (380) & $231.00 \pm 9.32$ & $193.60 \pm 5.51$ & $214.80 \pm 5.06$ & $109.20 \pm 5.52$ \\
\hline St. John's Wort Supplement (760) & $253.20 \pm 5.24$ & $176.80 \pm 7.81$ & $231.20 \pm 10.58$ & $113.80 \pm 4.87$ \\
\hline $\begin{array}{l}\text { St. John’s Wort Supplement } \\
(1520)\end{array}$ & $266.40 \pm 12.78^{*}$ & $160.80 \pm 6.38^{*}$ & $238.00 \pm 28.69 *$ & $90.80 \pm 6.44 *$ \\
\hline
\end{tabular}

Five mice were used in each group

${ }^{*} \mathrm{p}<0.05$ (One way ANOVA and Post hoc Tukey-Kramer multiple comparison test was done individually for male, female and different parameters) 
Cytological Studies on Micronucleus Test

The sub-acute treatment with SJWS caused a significant increase in the frequency of micronucleatedPCE at $760(p<0.05)$ and $1520(p<0.01) \mathrm{mg} / \mathrm{kg} / \mathrm{day}$. The ratio of $\mathrm{PCE} / \mathrm{NCE}$ in all the treatment groups was not affected at any of the doses as compared to the values obtained in the control group (Table 1).

\section{Cytogenetic Analysis for Meiotic Chromosomes}

The frequency of aneuploids was found to increase significantly at $760(\mathrm{p}<0.05)$ and $1520(\mathrm{p}<0.01)$ $\mathrm{mg} / \mathrm{kg} /$ day doses of SJWS. At these doses, the percent polyploids and the total percent aberrations were also significantly $(\mathrm{p}<0.05)$ increased as compared to the values obtained in the control group (Table 2).

\section{Cytological Analysis of Spermatozoa}

The treatment with SJWS caused a significant $(p<0.05)$ increase in the frequency of banana shaped, swollen achrosome and triangular head type of sperm abnormalities at the high dose $(1520 \mathrm{mg} / \mathrm{kg} /$ day $)$ of SJWS. At this dose, the percent total spermatozoa abnormalities was also significantly $(\mathrm{p}<0.05)$ increased as compared to the values obtained in the control group (Table 3).

Estimation of Proteins and Nucleic Acids in the Hepatic Cells

The treatment with SJWS failed to cause any significant changes in the hepatic levels of proteins. However, the concentrations of RNA and DNA in the liver were found to deplete significantly $(\mathrm{p}<0.05)$ at the high dose $(1520 \mathrm{mg} / \mathrm{kg} /$ day $)$ of SJWS as compared to the values obtained in the control group (Table 4).

\section{Estimation of Proteins and Nucleic Acids in the Testicular Cells}

The concentrations of proteins and RNA were not affected in the testicular tissue. However, there was a significant $(p<0.05)$ decrease in the testicular levels of DNA at $1520 \mathrm{mg} / \mathrm{kg} /$ day of SJWS as compared to the values obtained in the control group (Table 4).

\section{Estimation of MDA and NP-SH in the Hepatic Cells}

The hepatic levels of MDA were not affected at the lower doses (380 and $760 \mathrm{mg} / \mathrm{kg} /$ day) of SJWS. However, a significant $(\mathrm{p}<0.05)$ increase of MDA concentrations in the liver was observed at the high dose $(1520 \mathrm{mg} / \mathrm{kg} /$ day) of SJWS. At the same dose the hepatic concentrations of NP-SH were significantly $(\mathrm{p}<0.05)$ reduced as compared to the values observed in the control group (Table 5).
Estimation of MDA and NP-SH In the Testicular Cells

The testicular levels of MDA and NP-SH were significantly $(\mathrm{p}<0.05)$ increased and decreased respectively at the high dose $(1520 \mathrm{mg} / \mathrm{kg} / \mathrm{day})$ of SJWS as compared to the values obtained in the control group (Table 5).

\section{Discussion}

The treatment with SJWS significantly increased the frequency of micronucleated-PCE. These data clearly showed genotoxic effect of SJWS in bone marrow erythrocytes of Swiss albino mice. There are no parallel studies on the genotoxic potentials of SJW (the major ingredient of SJWS), except the report [33] which showed that the ethanolic extract of SWJ failed to cause any chromosome aberrations in the bone marrow cells of Chinese hamster. The discrepancy between the results might be due the difference in species (Syrian hamster and Chinese hamster) used by Okpanyi et al. [33]. An earlier study showed such differences are bound to reflect marked changes in metabolism of drugs [34]. Furthermore, Okpanyi et al. [33] used ethanolic extract, which might be another basis for the observed discrepancy, because different extracts of SJW are known to differ in their chemical composition. A large number of reports are published on SJW with regard to the changes in its chemical constituents and discrepancies in the activity of its extracts and different fractions of the plant. For example, the $\mathrm{CO}_{2}$ extract of SJW is found to contain $30.14 \%$ hyperforin, whereas, in the methanolic extract, the concentration of hyperforin was $4.67 \%$ [35]. Discrepancies are also observed in the activity of different fractions of extracts from the same plant. Polyphenol fraction exhibits the immunostimulating activity, whereas, the lipophilic fraction of the plant exhibits immunosuppressant properties with respect to cellular and humoral immune response [36].

Rosemary and its constituents, carnosol or carnosic acid were found to inhibit genotoxicity caused by benzo[a]pyrene in human bronchial cells [15]. However, in general the in vitro results are difficult to be compared to the in vivo results [37]. Although, the constituents (caffeic acid, rosmarinic acid, carnosol or carnosic acid) of RM are reported to be antioxidants [15, 16, 17], the content of RM in SJWS is too little to protect against the toxic effects of SJW. The other minor ingredient (SP) also was found to protect against the CP-induced genetic damage [23]. The doses used in this study were 200, 400 or $800 \mathrm{mg} / \mathrm{kg}$ body weight and the duration of treatment was 2 weeks. The content of SP in SJWS used in the present study was $40 \mathrm{mg}$, which is very small quantity to protect against the genotoxicity of SJW present in SJWS.

The increase in the frequency of micronuclei observed in the present study is consistent with depletion of DNA observed in the same study. The exact mechanism of the formation of micronuclei is not known. However, it 
seems quite likely that there must have been bioactivation of the SJW ingredients (flavonols and quercetin) to alkylating intermediates [7]. In an earlier study, the alkylating intermediates of phytotoxins were found to cause genotoxicity by reacting with cellular macromolecules including DNA [38]. The in vitro experiments on protection against DNA adducts by RM and its constituents (carnosol or carnosic acid) caused by benzo [a]pyrene stands no comparison in view of the possible differences with the present in vivo study [37]. Although there are no direct experiments on the effect of SP on DNA, it was found to protect against the genetic damage caused by CP [23]. Nevertheless, the dose of SP $(200-800 \mathrm{mg} / \mathrm{kg})$ is no comparison to the content of SJW in SJWS.

During the current experiment, a significant increase in MDA and decrease of NP-SH levels was observed in the hepatic cells of mice in different groups. The results of biochemical parameters of hepatic cells showed a significant increase of MDA and decrease of NP-SH respectively. These data correspond to an earlier report on observed effect of SJW on histopathological changes that revealed a severe damage in both livers and kidneys of wister rats [5]. The data obtained clearly indicated a weakening of the antioxidant defense system in the hepatic cells which might have been responsible for the induction of micronuclei. The results of the present study are further supported by earlier findings. Cetiner et al. [39] reported that lipid peroxidation, mediated by oxygen free radicals, might be an important cause of deterioration and damage to cell membranes, resulting in toxic injury to bone marrow cells. Previous studies also confirmed that lipid peroxides influence the induction of mutagenesis as evidenced by the formation of micronuclei [40, 41]. Although, both the minor ingredients (RM and SP) and their constituents are proven antioxidants $[17,20]$, the quantities are too little to protect against the oxidative potentials of SJW present in SJWS.

During present study, SJWS treatment increased the frequency of spermatozoa abnormalities such as banana shaped, swollen achrosome, triangular head and induced the chromosomal aberrations (aneuploids, polyploids and total aberrations) in the testes. Our data is in agreement with the earlier observations where SJW was reported to be mutagenic to sperm cells and showed spermicidal effect leading to inhibition of sperm motility [4]. These authors also demonstrated it to be mutagenic to sperm cells. These data corresponds with the observation of Ondrizek et al. [4] who showed SJW to possess spermicidal effect, as revealed by inhibition of sperm motility. These authors also demonstrated it to be mutagenic to sperm cells. Earlier studies demonstrated dependence of sperm abnormalities on chromosomalaberrations [28, 42]. The data on sperms and testes chromosomes are in corroboration with the depletion of testicular nucleic acids observed in the present study. The exact mode of action of is not known, however; it might be related with biochemical changes observed in the testes, which showed increase of MDA and depletion of DNA and NP-SH.
The changes observed in the testes might be responsible for the clastogenic effect in the target cells. This observation confirms the previous reports in the literature, which found sensitization of the target cells of oxidant status [39, 43]. Cetiner et al. [39] reported that lipid peroxidation mediated by oxygen free radicals, might be an important cause of destruction and damage to cell membranes, resulting in toxic injury to cells and tissues. In earlier studies, the deficiency of endogenous antioxidants has been described to interfere with meiosis and cause chromosomal anomalies, thereby disrupting the structural development of spermatozoa $[28,44]$. There are related studies on the sperm abnormalities caused by RM and/or its constituents. However, they are known to improve sperm motility [16]. SP was found to protect CP-induced genetic damage to germ cells in the dose range of 200 to $800 \mathrm{mg} / \mathrm{kg}$, which is much higher as compared to the SP contents of SJWS and might be too less to protect the sperm abnormalities caused by SJW.

The role of the constituent/(s) present in SJW, RM and SP in the genotoxicity and biochemical changes observed in the present study is not known. However, the observed changes in the somatic and germ cells might be attributed to the mutagenic constituents (terpenes, sesquiterpenes, tannins and flavonoids [biflavones, quercetin]) present in SJW [7, 10, 33, 45, 46]. Earlier studies showed flavonols, quercetin and myricetin to cause genotoxicity without metabolic activation [47]. Many flavonoids and related compounds, such as quercetin, kaempferol, neohesperidin and dihydrochalcones were shown to cause chromosomal anomalies by micronucleus test [48-50]. Subsequent studies on flavonoids revealed their genotoxicity in the micronucleus assay in mouse bone marrow erythrocytes, human lymphocytes; V79 cell line [49] to be caused by the free radicals [50] and DNA damage [51]. Von der Hude et al. [52] found some terpenoids to develop mutagenicity in Salmonella typhimurium in the presence of S9 mix. The active principles (hypericin and hyperforin) might not have contributed to the toxicity of SJW in view of the fact that the activity of hypericin is related to the influence of light $[11,12,53]$ and hyperforin has the tendency to degrade at temperatures higher than $-70^{\circ} \mathrm{C}$ [13].

Considering the quantity of different ingredients (SJW, RM and SP) in SJWS, it is likely that SJW, as the major ingredient, might be responsible for the observed toxicity of SJWS. The exact mechanism of the observed genotoxic and biochemical supposed to be caused SJW is not known. However; our results on biochemical analysis, revealed the role of free radicals in the induction of the observed genotoxicity appears to be mediated through the reactive oxygen species. Our results are supported by recent studies, which have drawn a clear relation between the genesis of free radicals and the induction of genotoxicity $[54,55]$ Nevertheless, these data contradicts the literature reports on different extracts of SJW and a large number of constituents (terpenes, sesquiterpenes, tannins and flavonoids (quercetin and biflavones) of SJW, that are found to be antioxidants and known to protect 
against genotoxicity and/or carcinogenicity [56-62]. The discordance in these results might be due to the redox state of the cells and the pre-loading of SJWS much before the exposure of the tissues to oxidant injury. The difference in duration and quantity of exposures might have determined the proportion of antioxidant/oxidant ratio and the related outcome. Furthermore, it is difficult to correlate the effect of SJWS as a whole drug and the reported effects of the different constituents of SJWS. Since, SJW is known to influence the cytochrome P450 and mixed functional oxidase system [24], it is possible that the metabolism of some of the constituents of SJW might have been inhibited as a result of the known activity of SJWS as a whole product.

Taken together, the results obtained in the present study revealed genotoxicity of SJWS, which might be related to the SJW, as the major ingredient. These changes might be attributed to the epigenetic mechanisms as revealed by an increase in the concentrations of MDA and a decrease of NP-SH levels in hepatic and testicular cells. In view of the additive and supra-additive effects of plant's multiple constituents, the mechanism of action of the different constituents present in SJW is uncertain. There is scope for synergy through pharmacokinetic and/or pharmacodynamic interactions, which might result in beneficial and/or harmful results [63]. Nevertheless, the observed effect might be related to the combined and/or individual effects of the different constituents of SJW, excluding hypericin, which is known to activate under the influence of light and hyperforin, which is unstable at variations in temperature above $-70^{\circ}$ C. Further experiments are suggested on clinical and experimental toxicity of SJWS under exposure to light and also at varying temperatures to determine the exact mechanism of action and the role of active principles of SJW.

Acknowledgement: The author is thankful to King Abdulaziz City for Science and Technology, Riyadh, Kingdom of Saudi Arabia for sanction of the grant to conduct research on herbal drugs (PROJECT AR-21-41).

\section{References}

1. Saller, R.; Melzer, J.; Reichling, J.: [St. John's Wort (Hypericum perforatum): a plurivalent raw material for traditional and modern therapies] Forsch Komplementarmed Klass Naturheilkd. 2003, 10, Suppl.1, 33-40.

2. Jang, M.H.; Lee, T.H.; Shin, M.C.; Bahn, G.H.; Kim, J.W.; Shin, D.H.; Kim, E.H.; Kim, C.J.: Protective effect of Hypericum perforatum Linn (St. John's wort) against hydrogen peroxide-induced apoptosis on human neuroblastoma cells. Neurosci. Lett. 2002, 329(2), 177-180.

3. Hunt, E. J.; Lester, C. E.; Lester, E. A.; Tackett, R. L.: Effect of St. John's wort on free radical production. Life Sci. 2001, 69, 181-90.

4. Ondrizek, R. R.; Chan, P. J.; Patton, W. C.; King, A.: Inhibition of human sperm motility by specific herbs used in alternative medicine. J. Assist. Reprod Genet. 1999, 16(2), 87-91.

5. Gregoretti, B.; Stebel, M.; Candussio, L.; Crivellato, E.; Bartoli, F.; Decorti, G.: Toxicity of Hypericum perforatum (St. John's wort) administered during pregnancy and lactation in rats. Toxicol. Appl. Pharmacol. 2004, 200, 201-205.

6. Golsch, S.; Vocks, E.; Rakoski, J.; Brockow, K.; Ring, J.: [Reversible increase in photosensitivity to UV-B caused by St. John's wort extract] Hautarzt. 1997, 48, 249-252.

7. No authors listed. Final report on the safety assessment of Hypericum perforatum oil. Int. J. Toxicol. 2001, 20, Suppl. 2, 31-39.

8. Kumper, H.: [Hypericum poisoning in sheep]. Tierarztl Prax. 1989, 17(3):257-261.

9. Hostanska, K.; Reichling, J.; Bommer, S.; Weber, M.; Saller, R.: Aqueous ethanolic extract of St. John's wort (Hypericum perforatum L.) induces growth inhibition and apoptosis in human malignant cells in vitro. Pharmazie. 2002, 57, 323-331.

10. Firenzuoli, F.; Gori, L.; Crupi, A.; Neri, D.: [Flavonoids: risks or therapeutic opportunities?] Recenti. Prog. Med. 2004, 95, 345-351.

11. Miskovsky, P.: Hypericin--a new antiviral and antitumor photosensitizer: mechanism of action and interaction with biological macromolecules. Curr. Drug Targets. 2002, 3, 55-84.

12. Laggner, H.; Schmid, S.; Goldenberg, H.: Hypericin and photodynamic treatment do not interfere with transport of vitamin C during respiratory burst. Free Radic Res. 2004, 38, 1073-1081.

13. Orth, H. C.; Rentel, C.; Schmidt, P. C.: Isolation, purity analysis and stability of hyperforin as a standard material from Hypoericum perforatum L. $J$. Pharm. Pharmacol. 1999, 51, 193-200.

14. Donella-Deana, A.; Appendino, G.; Borsarini, A.; Caniato, R.; Garbisa, S.: Hyperforin inhibits cancer invasion and metastasis. Cancer Res. 2004, 64, 62256232.

15. Offord, E. A.; Mace, K.; Ruffieux, C.; Malnoe, A.; Pfeifer, A. M.: Rosemary components inhibit benzo[a]pyrene-induced genotoxicity in human bronchial cells. Carcinogenesis, 1995, 16(9), 20572062.

16. Al-Sereiti, M. R.; Abu-Amer, K. M.; Sen, P.: Pharmacology of rosemary (Rosmarinus officinalis Linn.) and its therapeutic potentials. Indian J. Exp. Biol. 1999, 37(2), 124-130.

17. Makino, T.; Ono, T.; Liu, N.; Nakamura, T.; Muso, E.; Honda, G.: Suppressive effects of rosmarinic acid on mesangioproliferative glomerulonephritis in rats. Nephron, 2002, 92(4), 898-904.

18. Sancheti, G.; Goyal, P. K.: Effect of Rosmarinus officinalis in modulating 7, 12-dimethylbenz (a) anthracene induced skin tumorigenesis in mice. Phytother Res. 2006, 20(11), 981-986.

19. Anadon, A.; Martinez-Larrafiaga, M. R.; Martinez, M. A.; Ares, I.; Garcia-Risco, M. R.; Senorans, F. J.; 
Reglero, G.: Acute oral safety study of rosemary extracts in rats. J. Food Prot. 2008, 71(4), 790-795.

20. Chamorro, G.; Salazar, M.; Favila, L.; Bourges, H.: [Pharmacology and toxicology of Spirulina alga. Rev. Invest. Clin. 1996, 48(5), 389-399.

21. Khan, Z.; Bhadouria, P.; Bisen, P. S.: Nutritional and therapeutic potential of Spirulina. Curr. Pharm. Biotechnol. 2005, 6(5), 373-379.

22. Jetley, U. K.; Choudhary, M.; Fatma, T.: The impact of physical stresses on the growth of cyanobacterium Spirulina platensis-S5. J. Environ. Sci. Eng. 2004, 46(4), 303-311.

23. Chamorro-Cevallos, G.; Garduno-Siciliano, L.; Barron, B. L.; Madrigal-Bujaidar, E.; Crua-Vega, D. E.; Pages, N.: Chemoprotective effect of Spirulina (Arthrospira) against cyclophosphamide-induced mutagenicity in mice. Food Chem. Toxicol. 2008, 46(2), 567-574.

24. Branda, R. F.; Powden, C.; Brooks, E. M.; Yildirim, Z.; Naud, S. J.; McCormack, J. J.: Vitamin E but not St. John's wort mitigates leucopenia caused by cancer chemotherapy in rats. Transl. Res. 2006, 48, 315-324.

25. Chan, P. K.; O’Hara, G. P.; Hayes, A. W.: Principles and Methods for Acute and Sub-chronic toxicity, In: Principles and Methods of Toxicology. A.W. Hayes (ed.), Raven Press, New York, 1986, pp. 17.

26. Al-Yahya, A. A.; Al-Majed, A. A.; Al-Bekairi, A. M.; Al-Shabanah, O. A.; Qureshi, S.: Studies on the reproductive, cytological and biochemical toxicity of Ginkgo biloba in Swiss albino mice. J. Ethnopharmacol. 2006, 107, 222-228.

27. Schmid, W.: The micronucleus test. Mutat. Res. 1975, 31, 9-15.

28. Al-Shabanah, O. A.: Influence of captopril on spermatogenic dysfunction, spermatocyte chromosomes and dominant lethality in Swiss albino male mice. Res. Comm. Pharm. Toxicol. 1997, 2, 69-84.

29. Schacterle, G. R.; Pollack, R. L: A simplified method for quantitative assay for small amount of proteins in biological materials. Anal. Biochem. 1973, 51, 654655.

30. Bregman, A. A.: Laboratory Investigations and Cell Biology. John Willey and Sons, New York, 1983, pp. 51-60.

31. Ohkawa, H.; Ohishi, N.; Yagi, K.: Assay of lipid peroxides in animal tissues by thiobarbituric acid reactions. Anal. Biochem. 1979, 95, 351-358.

32. Sedlak, J.; Lindsay, R. H.: Estimation of total proteinbound and non-protein sulfhydryl groups in tissue with Ellman's reagent. Anal. Biochem. 1968, 25, 192.

33. Okpanyi, S. N.; Lidzba, H.; Scholl, B. C.; Miltenburger, H. G.: Genotoxicity of a standardized Hypericum extract. Arzneimittelforschung, 1990, 40, 851-855.

34. Lahdetie, J.; Peltonen, K.; Sjoblom, T.: Germ cell mutagenicity of three metabolites of 1,3-butadiene in the rat: induction of spermatid micronuclei by butadiene mono-, di-, and diolepoxides in vivo. Environ. Mol. Mutagen. 1997, 29(3), 230-239.
35. Dimpfel, W.; Schober, F.; Mannel, M.: Effects of a methanolic extract and a hyperforin-enriched CO2 extract of St. John's Wort (Hypericum perforatum) on intracerebral field potentials in the freely moving rat (Tele-Stereo-EEG). Pharmacopsychiat. 1998, Suppl 1, 30-35.

36. Evstifeeva, T. A.; Sibiriak, S. V.: [The immunotropic properties of biologically active products obtained from Klamath weed (Hypericum perforatum L.)] Eksp Klin Farmakol. 1996, 59, 51-54.

37. Ceconi, C.; Francolini, G.; Bastianon, D.; Gitti, G. L.; Comini, L.; Ferrari, R.: Differences in the effect of angiotensin-converting enzyme inhibitors on the rate of endothelial cell apoptosis: in vitro and in vivo studies. Cardiovasc Drugs Ther. 2007, 21(6), 423429.

38. Rietjens, I. M.; Martena, M. J.; Boersma, M. G.; Spiegelenberg, W.; Alink, G. M.: Molecular mechanisms of toxicity of important food-borne phytotoxins. Mol. Nutr. Food Res. 2005, 49, 131-158.

39. Centiner, M.; Sener, G.; Sehirli, A.O.; EksiogluDemiralp, E.; Ercan, F.; Sirvanci, S.; Gedik, N.; Akpulat, S.; Tecimer, T.; Yegen, B.C.: Taurine protects against methotrexate-induced toxicity and inhibits leukocyte death. Toxicol. Appl. Pharmacol. 2005, 209, 39-50.

40. Loeb, L. A.; James, E. A.; Waltersdorph, A. M.; Klebanoff, S. J.: Mutagenesis by the autoxidation of iron with isolated DNA. Proc. Natl. Acad. Sci.1988, 85(11), 3918-3922.

41. Premkumar, K.; Bowlus, C. L.: Ascorbic acid reduces the frequency of iron induced micronuclei in bone marrow cells of mice. Mutat. Res. 2003, 542(1-2), 99103.

42. Kelly, T. L., Li, E., Trasler, J. M.: 5-aza-2”deoxycytidine induces alteratikons in murine spermatogenesis and pregnancy outcome. J. Androl. 2003, 24, 822-830.

43. Babiak, R. M.; Campello, A. P.; Carnieri, E. G.; Oliveira, M.B.: Methotrexate: pentose cycle and oxidative stress. Cell Biochem. Funct. 1998, 16(4), 283-293.

44. Watanabe, T.; Endo, A.: Effects of selenium deficiency on sperm morphology and spermatocyte chromosomes in mice. Mutat. Res. 1991, 262, 93-99.

45. Ramos, A.; Rivero, R.; Visozo, A.; Piloto, J.; Garcia, A.: Parthenin, a sesquiterpene lactone of Parthenium hysterophorus L. is a high toxicity clastogen. Mutat. Res. 2002, 514, 19-27.

46. Van der Woude, H.; Alink, G. M.; Van Rossum, B. E.; Walle, K.; Van Steeg, H.; Walle, T.; Rietjens, I. M.: Formation of transient covalent protein and DNA adducts by quercetin in cells with and without oxidative enzyme activity. Chem. Res. Toxicol. 2005, 18, 1907-1916.

47. Hardigree, A. A.; Epler, J. L.: Comparative mutagenesis of plant flavonoids in microbial systems. Mutat. Res. 1978, 58(2-3), 231-239. 
48. Sahu, R. K.; Basu, R.; Sharma, A.: Genetic toxicological of some plant flavonoids by the micronucleus test. Mutat. Res. 1981, 89(1), 69-74.

49. Caria, H.; Chaveca, T.; Laires, A.; Rueff, J.: Genotoxicity of quercetin in the micronucleus assay in mouse bone marrow erythrocytes, human lymphocytes, V79 cell line and identification of kinetochorecontaining (Crest staining) micronuclei in human lymphocytes. Mutat. Res. 1995, 343 (2-3), 85-94.

50. Rueff, J.; Laires, A.; Gaspar, J.; Borba, H.; Rodrigues, A.: Oxygen species and the genotoxicity of quercetin. Mutat Res. 1992, 265, 75-81.

51. Duthie, S. J.; Johnson, W.; Dobson, V. L.: The effect of dietary flavonoids on DNA damage (strand breaks and oxidized pyrimidines) and growth in human cells. Mutat. Res. 1997, 390 (1-2), 141-151.

52. Von der Hude, W.; Scheutwinkel-Reich, M.; Braun, R.: Bacterial mutagenicity of the tranquilizing constituents of Valerianaceae roots. Mutat. Res. 1986, 169, 23-27.

53. Bourke, C. A.: The effect of shade, shearing and wool type in the protection of Merino sheep from Hypericum perforatum (St John's wort) poisoning. Aust. Vet. J. 2003, 81, 494-498.

54. Blazovics, A.: Oxidative stress and liver disease. Orv. Hetil. 2004, 145(38), 1937-1942.

55. Ramprasath, V.R.; Shanthi, P.; Sachdanandam, P.: Evaluation of antioxidant effect of Semecarpus anacardium Linn. Nut extract on the components of immune system in adjuvant arthritis. Vascular Pharmacol. 2005, 42, 179-186.

56. Shibayama, Y.; Kawachi, A.,; Onimaru, S.; Tokunaga, J.; Ikeda, R.; Nishida, K.; Kuchiiwa, S.; Nakagawa, S.; Takamura, N.; Motova, T.; Takeda, Y.; Yamada, K.: Effect of pre-treatment with St. John's Wort on nephrotoxicity of cisplatin in rats. Life Sci. 2007, 81, 103-108.
57. Tieppo, J.; Vercelino, R.; Dias, A. S.; Silva Vaz, M.F.; Silveira, T. R.; Marroni, C. A.; Marroni, N. P.; Henriques, J. A.; Picada, J. N.: Evaluation of the protective effects of quercetin in the hepatopulmonary syndrome. Food Chem. Toxicol. 2007, 45, 1140-1146.

58. Ahmad, M. S.; Sheeba Afazal, M.: Amelioration of genotoxic damage by certain phytoproducts in human lymphocyte cultures. Chem. Biol. Interact. 2004, 149, 107-115.

59. De, S.; Ganguly, C.; Das, S.: Natural dietary agents can protect against DMBA genotoxicity in lymphocytes as revealed by single cell gell electrophoresis assay. Teratog. Carcinog. Mutagen. 2003, Suppl 1, 71-78.

60. Llopiz, N.; Puiggros, F.; Cespedes, E.; Arola, L.; Ardevol, A.; Blade, C.; Salvado, M. J.: Antigenotoxic effect of grape seed procyanidin extract in Fao cells submitted to oxidative stress. Agric. Food Chem. 2004, 52, 1083-1087.

61. Laabich, A.; Manmoto, C. C.; Kuksa, V.; Leung, D. W.; Vissvesvaran, G. P.; Karliga, I.; Kamat, M.; Scott, I. L.; Fawzi, A.; Kubota, R.: Protective effects of myricetin and related flavonols against A2E and light mediated-cell death in bovine retinal primary cell culture. Exp. Eye Res. 2007, 85, 154-165.

62. Majer, B. J.; Hofer, E.; Cavin, C.; Lhoste, E.; Uhl, M.; Glatt, H. R.; Mein, I. W.; Knasmuller, S.: Coffee diterpenes prevent the genotoxic effects of 2-amino-1methyl-6-phenylimidazo[4,5-b]pyridine (PhIP) and $\mathrm{N}$-nitrosodimethylamine in a human derived liver cell line $\left(\mathrm{HepG}_{2}\right)$. Food Chem. Toxicol. 2005, 43, 433441.

63. Spinella, M.: Herbal medicines and epilepsy: The potential for benefit and adverse effects. Epilepsy Behav. 2001, 2(6), 524-532. 